\title{
NILAI KESETARAAN GENDER PADA CERPEN DALAM BUKU TEKS BAHASA INDONESIA SMA
}

\author{
Ade Husnul Mawadah \\ FKIP Universitas Sultan Ageng Tirtayasa \\ email: adehusnul_29@yahoo.co.id
}

\begin{abstract}
Abstrak
Penelitian ini bertujuan mendeskripsikan nilai kesetaraan gender dalam buku teks Bahasa Indonesia SMA. Penelitian ini menggunakan desain analisis isi untuk menganalisis sikap, pandangan, dan citra tokoh laki-laki dan perempuan dalam cerpen-cerpen yang dimuat di buku pelajaran Bahasa Indonesia SMA. Hasil penelitian sebagai berikut. Pertama, tokoh laki-laki dalam cerpen pada umumnya memandang perempuan sebagai seseorang yang berhak mendapatkan kesempatan berkarier di luar rumah, teman dalam rumah tangga, teman berdiskusi, dan penentu keputusan. Kedua, peran perempuan yang paling menonjol adalah peran domestik. Sebagai pribadi, perempuan mempunyai keinginan mengaktualisasikan dirinya untuk mengembangkan potensi dirinya. Ketiga, aspek kesetaraan gender tampak pada sikap dan perilaku yang dikelompokkan menjadi tiga, yaitu saling memahami, saling menghargai, dan saling berbagi. Ketiga sikap dan perilaku tersebut merupakan wujud sinergitas dan kata kunci kesetaraan gender dalam hubungan bermasyarakat. Kesetaraan berarti bersinergi dalam berbagai bidang kehidupan.
\end{abstract}

Kata kunci: buku teks, kesetaraan gender, peran domestik, tokoh

\section{GENDER EQUITY IN SHORT STORIES IN INDONESIAN LANGUAGE TEXTBOOKS FOR SHS}

\begin{abstract}
This study aims to describe gender equity in Indonesian language textbooks for the senior high school (SHS). It used the content analysis design to analyze the attitudes, views, and images of male and female characters in the short stories in the textbooks. The findings are as follows. First, the male characters in the short stories generally see women as ones who deserve a career opportunity outside the home, friends in the household, friends in discussion, and decision makers. Second, women's most prominent role is the domestic role. As individuals, women have desire to actualize themselves to develop their potential. Third, the aspect of gender equity appears in three types of attitudes and behaviors, namely mutual understanding, mutual respect, and sharing. These are the manifestations of synergy and keywords in gender equity in social relations. Equity means synergy in various areas of life.
\end{abstract}

Keywords: textbooks, gender equity, domestic role, characters 


\section{PENDAHULUAN}

Dalam Sistem Pendidikan Nasional (Sisdiknas) di Indonesia, Mata Pelajaran Bahasa Indonesia memiliki kedudukan yang sangat penting karena Bahasa Indonesia memiliki peran strategis, yakni sebagai Bahasa Pengantar Pendidikan dan Bahasa Nasional. Bahkan, dalam Kurikulum Tahun 2013/Kurikulum Nasional (Kurnas), Bahasa Indonesia berkedudukan sebagai penghela Mata Pelajaran-Mata Pelajaran lain. Salah satu materi dalam Mata Pelajaran Bahasa Indonesia adalah sastra. Apabila kita mengacu pada tujuan pembelajaran sastra yang memberikan pengalaman berapresiasi dan berekspresi kepada siswa, kita dapat menarik simpulan bahwa pengajaran sastra tidak hanya memberikan fakta-fakta hafalan nama pujangga dan hasil karyanya, tetapi lebih jauh bertujuan untuk menanamkan nilai-nilai yang melibatkan sikap batin serta membentuk kepribadian siswa (UU Sisdiknas, 2003). Menurut Suyudi (2013:8) pengajaran sastra tidak hanya dapat membantu siswa memahami bahasa, tetapi juga dapat membentuk karakter siswa. Bahkan, Purwati (2011: 23) menyatakan bahwa sastra sangat efektif untuk menanamkan nilai moral, edukasi, dan akhlak pada siswa. Karya sastra dapat memberikan solusi untuk dunia pendidikan, baik untuk penanaman nilai-nilai akhlak maupun pengetahuan intelektual. Dengan demikian, dalam Pelajaran Bahasa Indonesia guru memiliki ruang untuk melakukan proses pembentukan karakter siswa melalui media karya sastra.

Upaya guru untuk membentuk karakter siswa dapat dilakukan dengan memanfaatkan buku pelajaran. Salah satu karakter yang dapat dibangun adalah memahami nilai-nilai kesetaraan gender. Buku pelajaran memiliki peran strategis dalam mengenalkan nilai-nilai tersebut kepada siswa. Beragam karya sastra yang digunakan guru sebagai bahan ajar, di antaranya terdapat dalam buku pelajaran. Buku pelajaran sebagai media interaksi individu siswa dalam menanamkan karakter yang baik (Sooraj, 2013:3). Karya sastra yang sering digunakan sebagai bahan penunjang materi ajar Bahasa Indonesia adalah cerita pendek (cerpen). Cerpen yang terdapat dalam buku pelajaran Bahasa Indonesia sering kali mengandung nilai-nilai kesetaraan gender. Melalui teks cerpen itulah, siswa dapat mengambil nilai-nilai positif, termasuk nilai-nilai kesetaraan gender yang tercermin dari pandangan, citra, dan peranan tokoh laki-laki dan perempuan. Pendidikan kesetaraan gender diharapkan dapat membentuk karakter siswa yang mampu memahami dan menghargai sesamanya, tanpa memandang perbedaan laki-laki atau perempuan (Rahmawati, 2017:47).

Nilai-nilai kesetaraan gender dalam hal ini mengarah pada nilai-nilai kesetaraan gender yang sesuai dengan kondisi masyarakat Indonesia yang plural, menjunjung tinggi budaya timur, dan mayoritas beragama Islam. Dalam pandangan Islam, akar kesetaraan gender berasal dari kesadaran bahwa Tuhan Yang Maha Kuasa menciptakan manusia dan alam semesta secara seimbang dan saling melengkapi. Bahkan, Murata (1997: 11) mengungkapkan bahwa dalam Asmaul Husna (sifat-sifat Allah Swt.), para ahli metafisik menyimpulkan bahwa Tuhan bersifat plural, mengingat terdapat sifat-sifat maskulin dan feminin dalam Asmaul Husna. Sifatsifat Tuhan tidak memihak pada gender manapun, Tuhan bersifat Rahman (kasih 
sayang), Haliim (lembut), Jamal (cantik), Wadud (pengasih), tetapi Tuhan juga memiliki sifat-sifat yang powerfull, seperti Qawi (kuat), Jabbar (yang memaksa), dan Malik (penguasa).

Tidak ada satu kata pun dalam nashnash Alquran yang tidak mempunyai makna karena semua itu berasal dari Allah Swt. Dengan menafsirkan lebih dalam, di luar tataran lahiriah yang relatif, segala sesuatunya pasti terkait dengan penciptaan kosmos, dan pasti ada maknanya. Seluruh kosmos berasal dari Tuhan, maka Tuhan mencintai alam semesta. Langit dan bumi darinya sebongkah utuh, kemudian bumi dipisahkan dari langit, maka langit mencintai bumi melalui curahan hujannya ke bumi. Dari diri Adam dipisahkan Hawa, maka Adam mencintai Hawa. Begitu pula Hawa akan cenderung kepada Adam karena Adam adalah tempat di mana ia berasal. Dengan demikian, dapat dikatakan bahwa sesungguhnya Tuhan menciptakan manusia dan alam semesta secara seimbang dan saling melengkapi. Oleh karena itu, satu sama lain harus saling menjaga dan bersinergi dalam berbagai hal.

Pandangannya tersebut disandingkan dengan konsep relasi gender dalam Kosmologi Cina. Keseimbangan yang diciptakan Tuhan dilukiskan dalam kerangka Yin dan Yang, yang bisa dipahami sebagai prinsip-prinsip eksistensi yang bersifat aktif dan reseptif atau laki-laki dan perempuan. Yin dan Yang merangkul satu sama lain dalam keselarasan dan perpaduan keduanya menghasilkan Sepuluh Ribu Hal, yakni segala sesuatu yang ada. Yin dan Yang adalah prinsip-prinsip perubahan dan simbol bagi seluruh gerakan di alam semesta.
Berdasarkan pandangan tersebut, kesadaran masyarakat terhadap kesetaraan gender yang mengacu pada persamaan hak sebagai manusia, makhluk Tuhan, perlu dibangun. Perbedaan kodrati lakilaki dan perempuan harus dimaknai sebagai alat untuk membangun kesalingan, satu sama lain saling melengkapi. Tidak ada lagi oposisi biner yang menegasikan jenis kelamin tertentu. Dengan demikian, relasi gender di masyarakat berlangsung harmonis dan selaras(Rahmawati, 2017:60).

Upaya membangun kesadaran masyarakat terhadap kesetaraan gender tersebut salah satunya dapat dilakukan melalui bidang pendidikan, khususnya melalui pelajaran Bahasa Indonesia, dengan memperhatikan dan memasukkan isu kesetaraan gender dan nilai-nilai humanis lainnya sebagai bahan dan media pembelajaran yang harus dikuasai oleh guru dengan mengaplikasikan prinsip-prinsip pembelajaran yang efektif (USAID PRIORITAS, 2013:78). Cerpen dengan unsur-unsur intrinsik dan ekstrinsik yang terkandung di dalamnya dapat dijadikan sebagai media penyampai pesan kesetaraan gender melalui analisis tokoh-tokoh dalam cerpen tersebut. Pandangan, citra, dan peran tokoh laki-laki dan tokoh perempuan dalam cerpen tersebut dianalisis untuk mengetahui apakah tokoh perempuan sudah dicitrakan sejajar dengan tokoh laki-laki dan apakah kedua jenis kelamin tersebut saling bersinergi dalam menjalani kehidupannya sehingga tidak terjadi bias gender.

Penciptaan sastra selalu bersumber dari kenyataan-kenyataan yang hidup di masyarakat. Secara lebih sederhana, karya sastra menggambarkan unsur-unsur masyarakat yang terdiri dari laki-laki dan perem- 
puan. Interaksi yang terjalin di antara keduanya merupakan tema yang menarik untuk dikajisebab menyangkut hubungan antara dua jenis kelamin, yang membentuk tatanan kehidupan masyarakat (Sugihastuti dan Septiawan, 2010: 82).

Dalam dunia sastra, khususnya sastra Indonesia, istilah citra (image) selalu melekat dengan istilah pencitraan (imagery). Citra memiliki banyak arti dan konotasi. Secara umum pengertian citra meliputi penggunaan bahasa yang menggambarkan objek, aksi, perasaan, pikiran, ide, ungkapan pikiran, dan berbagai pengalaman sensoris, yang diungkapkan lewat katakata oleh pengarang sehingga mudah dipahami oleh pembaca. Pandangan positif dan negatif tersebut kemudian membentuk citra jenis kelamin. Citra laki-laki dan citra perempuan terbentuk berdasarkan pandangan tersebut. Citra perempuan dan laki-laki itu mengakar di masyarakat kita, termasuk di benak penulis sastra sebagai anggota masyarakat. Selain citra, peran perempuan dalam masyarakat juga menjadi pembahasan yang selalu menarik perhatian. Manusia sebagai anggota masyarakat dituntut untuk berperan sesuai dengan "keinginan" masyarakat.

\section{METODE}

Penelitian ini adalah penelitain kualitatif dengan menggunakan desain penelitian analisis isi. Analisis isi adalah suatu teknik yang memungkinkan peneliti untuk mempelajari tingkah laku manusia (Fraenkel \& Wallen, 2007:483). Metode ini digunakan untuk menganalisis sikap, pandangan, dan citra tokoh laki-laki dan perempuan dalam cerpen-cerpen yang dimuat di buku pelajaran Bahasa Indonesia SMA, sehingga ditemukan nilai-nilai ke- setaraan gender yang terkandung dalam cerpen-cerpen tersebut dan menunjukkan kelayakan isi cerpen-cerpen tersebut ditinjau dari nilai-nilai kesetaraan gender. Untuk mendeskripsikan data-data akan digunakan pendekatan gender, yaitu pendekatan yang mengkaji, menafsirkan, menilai karya sastra dengan cara-cara dan pandangan baru. Adapun teknik penelitian yang penulis gunakan adalah studi pustaka dan teknik analisis.

Korpus data penelitian ini adalah cerpen-cerpen Indonesia yang dimuat dalam buku pelajaran Bahasa Indonesia SMA. Sebagai sumber data primer adalah pandangan, citra, dan peran tokoh perempuan dalam cerpen-cerpen yang terdapat di buku pelajaran Bahasa Indonesia SMA tahun ajaran 2011/2012. Dari 22 cerpen yang terdapat dalam buku pelajaran tersebut, dipilih sebelas cerpen, yaitu: 1) "Ajaran Kehidupan Seorang Nenek" karya NH. Dini, 2) "Hipnotis" karya Euis Sulastri, 3) "Prosesi" karya M. Shoim Anwar, 4) "Cut" karya Asma Nadia, 5) "Kebebasan" karya Sofia, 6) "Maling" karya Lidya Kartika Dewi, 7) "Sang Primadona" karya A. Mustofa Bisri, 8) "Buroq" karya Ratih Kumala, 9) "Ebola" karya Soeprijadi Tomodihardjo, 10) "Arloji Sumiani" karya Gde Aryantha Soethama, dan 11) "Batu Menangis" karya Ismet Fanany. Secara keseluruhan prosedur pengumpulan data dalam proses penelitian ini adalah mengumpulkan literatur buku-buku pelajaran Bahasa Indonesia SMA yang digunakan di SMA Negeri Kota Serang pada tahun ajaran 2011/2012, menentukan sampel penelitian, yaitu cerpen-cerpen yang berisi aspek gender, membaca cerpen-cerpen yang dianalisis secara berulang-ulang, menganalisis unsur-unsur intrinsik cer- 
pen yang dijadikan sampel penelitian, mengidentifikasi pesan-pesan simbolik sehingga menghasilkan catatan-catatan atau kutipan-kutipan (kata, frasa, dan kalimat) yang menggambarkan pandangan, citra, dan peran tokoh perempuan, menganalisis nilai-nilai kesetaraan gender melalui analisis pandangan, citra, dan peran tokoh laki-laki dan perempuan dalam menjalani kehidupannya, kemudian menunjukkan nilai-nilai kesetaraan gender, menginventarisasikan semua temuan ke dalam tabel data, membuat simpulan, dan menyusun laporan penelitian.

\section{HASIL DAN PEMBAHASAN Pandangan Tokoh Laki-Laki dan Perempuan}

Analisis pandangan tokoh laki-laki dan perempuan yang terdapat dalam setiap cerpen dilakukan untuk mengetahui pandangan laki-laki terhadap perempuan dan pandangan perempuan terhadap laki-laki. Tahapan analisis ini dilakukan dengan melihat hubungan serta keterkaitan lakilaki dan perempuan yang didasarkan pada tahapan kerangka kerja/prosedur analisis gender dalam masyarakat (Mukhopadhyay, 2005:18). Berdasarkan data analisis diperoleh gambaran bahwa laki-laki dalam cerpen-cerpen yang dianalisis pada umumnya memandang perempuan sebagai seseorang yang berhak mendapatkan kesempatan berkarier di luar rumah, teman dalam rumah tangga, teman berdiskusi, dan penentu keputusan. Misalnya pada cerpen "Ajaran Kehidupan Seorang Nenek" karya NH Dini, tokoh Aku memiliki pandangan bahwa perempuan berhak memutuskan hal terbaik dalam hidupnya. Dia berani mengambil sikap untuk menunjukkan pandangannya tentang kemerde- kaan sebagai perempuan. Perempuan yang terkungkung adat Bali.

Akhirnya, suamiku menjemput dan berkata bahwa ibunya menyetujui semua keinginanku untuk kurang berperan sebagai penyelenggara aneka keperluan tradisi dan upacara. Kukatakan bahwa tidak ada gunanya sekolahku bertahun-tahun jika akhirnya hanya mengurusi upacaraupacara yang sebenarnya dapat diserahkan kepada orang lain.

Berdasarkan kutipan di atas, terlihat bahwa tokoh Aku memiliki pandangan yang berbeda tentang ritual adat di masyarakat Bali. Ia menganggap ritual adat itu membuat dirinya tidak merdeka. Waktunya tersita untuk mengurusi hal-hal yang berkaitan dengan ritual adat. Pandangan tersebut menunjukkan bahwa tokoh Aku merupakan pribadi yang kritis dan berjiwa merdeka.

Tokoh Suami pada cerpen tersebut memiliki pandangan yang terbuka. Ia mengakomodir keinginan istrinya untuk tidak berperan penuh dalam ritual adat tersebut. Ia menjadi tokoh penengah bagi istri dan ibunya. Dengan demikian, dapat dikatakan bahwa sebagai suami, ia adalah sosok yang bertanggung jawab atas persoalan yang terjadi di keluarganya. Selain itu, ia juga sosok yang sangat memahami dan mengakomodir keinginan istrinya.

\section{Citra Tokoh Laki-Laki dan Perempuan}

Analisis citra tokoh dibagi menjadi dua, yaitu citra fisik dan non-fisik. Citra setiap tokoh dalam cerpen-cerpen yang dianalisis ini tergambar sangat jelas. Citra perempuan yang dominan adalah perempuan dalam wilayah domestik. Perempu- 
an banyak dicitrakan sebagai istri yang mengurusi urusan domestik rumah tangga. Meskipun ada yang dicitrakan sebagai perempuan bekerja di wilayah publik, tokoh perempuan yang demikian itu tetap tidak melepaskan peran pentingnya dalam wilayah domestik rumah tangga. Hal tersebut menunjukkan bahwa perempuan memiliki kemampuan mengembangkan kariernya di ruang publik, tetapi tetap mampu melaksanakan tugasnya dengan baik dalam ruang domestik rumah tangganya. Dengan demikian, karier berjalan baik tanpa mengorbankan keluarga. Misalnya pada cerpen "Primadona" karya A. Mustofa Bisri. Citra tokoh Aku dalam cerpen tersebut adalah perempuan mandiri yang mampu menggali potensi diri dan memanfaatkan potensinya untuk mendapatkan materi dan citra tokoh suami Aku adalah laki-laki bijaksana yang memberikan keleluasaan kepada istrinya untuk terus berkarier di dunia entertainment. Dia tidak berkeberatan ketika istrinya memilih untuk tetap menekuni profesinya sebagai artis populer, meskipun sudah berkeluarga.

Begitulah, di awal-awal perkawinan, semua berjalan baik-baik saja. Setelah berbulan madu yang singkat, aku kembali menekuni kegiatanku seperti biasa. Suamiku pun tidak keberatan.

Pada fenomena yang demikian itu, rumah tangga menjadi tanggung jawab bersama. Tidak ada pembedaan ruang gerak baik laki-laki maupun perempuan (Ervanitaki, 2017:1-11). Tanggung jawab mencari nafkah atau bekerja tidak mutlak bagi laki-laki dan tanggung jawab perempuan untuk mengurus rumah tangga tidak mutlak bagi perempuan. Kedua tugas tersebut dilakukan bersama secara sinergis, sehingga keseimbangan peran dapat berjalan dengan baik.

Dalam kaitannya dengan uraian di atas, dapat dikatakan bahwa citra yang muncul dalam cerpen-cerpen yang dianalisis pada penelitian ini menunjukkan bahwa sesungguhnya laki-laki dan perempuan dapat melepaskan diri dari nilainilai tradisional yang patriarkal dan dianggap secara umum sebagai suatu hal yang bersifat kodrati. Perempuan dan laki-laki dapat melepaskan diri dari citra yang dibentuk masyarakat konvensional, kemudian menjadi pribadi yang saling menghargai dan mau berbagi peran. Oleh karena itu, gambaran yang ada dalam cerpen-cerpen tersebut adalah gambaran citra perempuan dan laki-laki yang diidamkan oleh masyarakatnya.

\section{Peranan Tokoh Laki-laki dan Perempuan}

Analisis selanjutnya adalah peranan tokoh yang mencakup peran domestik dan peran publik. Berdasarkan analisis peran dalam cerpen-cerpen yang dianalisis tersebut, peran perempuan yang paling menonjol adalah peran domestik. Salah satunya adalah pada cerpen "Cut" karya Asma Nadia. Dalam hubungan rumah tangga, Zein dan Cut Rani menjalankan perannya sebagai suami dan istri dengan baik. Peran keduanya dibedakan secara jelas, namun tetap dilakukan secara sinergis. Zein berperan sebagai suami yang bekerja di ruang publik untuk mencari nafkah agar dapat memenuhi kebutuhan hidup istri dan anaknya. Cut Rani berperan sebagai istri yang bertanggung jawab pada wilayah domestik rumah tangga, seperti berbelanja ke pasar, memasak, dan meng- 
urus anak. Dengan kata lain, Cut Rani murni berperan sebagai ibu rumah tangga. Peran kedua tokoh tersebut dalam urusan rumah tangga sangat terlihat jelas. Meskipun demikian, Zein sebagai suami tetap menghargai Cut Rani. Bahkan, ia membantu tugas Cut Rani sebagai istri, seperti mengantar Cut Rani ke pasar dan mengurus anak mereka.

Perbedaan peran di wilayah publik dan domestik tersebut tidak memunculkan tingkatan status keduanya. Hal yang terlihat adalah keseteraan peran. Meskipun dibedakan secara jelas, keduanya saling menghargai satu sama lain. Bagi Zein maupun Cut Rani menjalankan rumah tangga membutuhkan peran satu sama lain. Oleh karena itu, tidak ada timbangan peran, keduanya memiliki peran yang seimbang dan saling melengkapi.

Pemahaman tentang relasi gender yang seimbang dan saling bersinergi dapat dimulai dari rumah tangga adalah dasar utama yang sangat menentukan keberhasilan pembinaan karakter bangsa. Ini sejalan dengan tuntutan Islam karena secara langsung maupun tidak langsung pembinaan diawali dengan kiprah seorang perempuan dalam keluarga. Maskulinitas dan feminitas pada tataran manusia mempunyai sisi positif dan negatifnya, yang keduanya saling melengkapi, The Tao of Islam (Murata, 1997:11).

Laki-laki dan perempuan tidak ada yang lebih dominan, kesemuanya setara dan memiliki fungsi dan derajat yang sama mulia sebagai khalifah di muka bumi (Mazaya, 2014:234). Laki-laki dan perempuan memang berbeda, atas perbedaan tersebut kesetaraan mutlak tidak mungkin dicapai karena sejatinya laki-laki dan perempuan itu berbeda. Hal baik yang harus dilaku- kan adalah mendorong kaum perempuan untuk memaksimalkan potensi-potensi yang terdapat dalam dirinya sebagai perempuan dan menjadi pribadi unggul atas potensi feminin yang dimilikinya itu utuk menjadi insan yang mulia.

\section{Nilai-nilai Kesetaraan Gender}

Hasil analisis terhadap citra, pandangan, dan peran tokoh dalam cerpen menjadi landasan untuk menganalisis nilai-nilai kesetaraan gender yang terdapat dalam setiap cerpen. Pembicaraan nilai-nilai kesetaraan gender dalam pembahasan ini dibagi dalam tiga wilayah interaksi, yaitu nilai-nilai kesetaraan gender dalam interaksi suami dan isteri (Misalnya, Cut dan Zein pada cerpen "Cut" karya Asma Nadia), interaksi orang tua dan anaknya (Misalnya, tokoh Ibu dan Qatrun, anak lakilakinya pada cerpen "Buroq" karya Ratih Kumala), dan interaksi bertetangga (Misalnya, tokoh Pak Cokro dan Bu Marni pada cerpen "Maling" karya Lidya Kartika Dewi).

Dunia terdiri atas perempuan dan lakilaki, membangun kesetaraan perlu dipahami bukan untuk menyetarakan perempuan dan laki-laki dengan ukuran lakilaki, bukan menjadikan perempuan sama dengan laki-laki. Perempuan dan laki-laki membutuhkan kesalingan dalam perbedaan jenis kelamin, terkait cinta, kebudayaan, masyarakat, ataupun politik. Diciptakannya makhluk dengan jenis kelamin berbeda, sesungguhnya untuk saling melengkapi, saling menghormati, dan saling mengasihi agar tercipta kehidupan damai dan bahagia (Haryanti dan Sawana, 2014: 240).

Nilai-nilai kesetaraan gender dalam wilayah interaksi suami dan istri dapat 
dijumpai dalam keluarga. Rekonstruksi sosial untuk kesetaraan gender dimulai dari keluarga karena keluarga merupakan elemen strategis dalam mewujudkan kesetaraan gender. Unit masyarakat keluarga terdiri dari dua orang atau lebih yang hidup bersama, saling tergantung dengan keterikatan aturan dan emosional, di mana masing-masing anggota keluarga memiliki perannya masing-masing (Djoharwinarlien, 2012:15). Dalam konsep tersebut tidak ada judgment yang secara langsung menyatakan bahwa perempuan sebagai anggota keluarga akan dilekati tugas dalam sektor privat dan laki-laki sebagai anggota keluarga bertanggung jawab dalam urusan publik.

Kesetaraan antara laki-laki dan perempuan dalam sebuah rumah tangga, bukan berarti memposisikan laki-laki dan perempuan harus diperlakukan sama. Memperlakukan laki-laki dan perempuan secara sama dalam semua keadaan justru menimbulkan bias gender. Memperlakukan sama antara laki-laki dan perempuan dalam kerja rumah tangga pada satu keadaan, misalnya, suami juga berkewajiban mengurus anaknya, sama halnya istri mempunyai kewajiban mengurus anaknya. Artinya kewajiban mengurus anak tidak mutlak menjadi kewajiban istri semata, tetapi merupakan kewajiban bersama.

Pada relasi antara laki-laki dan perempuan di rumah tangga (suami istri) dalam cerpen-cerpen tersebut, tokoh menganggap pasangan hidup atau jodoh sebagai "pakaian" dan suami istri adalah satu untuk lainnya. Sebagai pakaian satu untuk lainnya, suami dan istri memerlukan sikap saling membantu, saling mendukung, saling melindungi, dan saling mencocoki tubuh. Seperti diungkapkan oleh Nurcholish Madjid, sebagai perhiasan, suami atau istri saling menunjukkan rasa santun, cinta-mencintai, dan memperlihatkan kebahagiaan; dan sebagai perlindungan, masing-masing suami dan istri berkewajiban saling menjaga nama, kehormatan, dan hak-hak pribadinya. Tentu saja, hubungan yang serba "saling" itu hanya dapat diwujudkan dalam wujud relasi yang setara dan seimbang, bukan dalam relasi yang timpang di mana satu pihak mendominasi pihak lainnya.

Perbedaan gender sesungguhnya merupakan hal yang biasa saja sepanjang tidak mengakibatkan ketidakadilan gender (gender inequalities). Pada cerpen-cerpen Indonesia yang dianalisis dalam penelitian ini, perbedaan gender menjadi hal wajar karena laki-laki dan perempuan dalam cerpen ini saling bersinergi dan saling melengkapi dalam kekurangan satu sama lainnya. Kedua jenis kelamin tersebut berusaha saling memahami, menghargai, dan saling berbagi. Baik laki-laki maupun perempuan selalu bersikap dewasa dalam menghadapi konflik sehingga relasi di antara keduanya berjalan harmonis. Secara garis besar, aspek kesetaraan gender yang terdapat dalam cerpen-cerpen yang dianalisis terlihat dari sikap dan perilaku yang dikelompokkan menjadi tiga, yaitu saling memahami, saling menghargai, dan saling berbagi.

Sikap saling memahami salah satunya terlihat pada cerpen "Arloji Sumiani" karya Gde Aryantha Soethama. Pada cerpen tersebut hubungan rumah tangga yang dijalani oleh tokoh saya dan Maya, istrinya berjalan baik di antara konflik batin masa lalu yang akhirnya berhasil diselesaikan dengan saling memahami. Sikap tersebut membuat hubungan rumah tangga mereka baik-baik saja.

Sikap saling menghargai salah satunya 
terdapat pada cerpen "Ajaran Kehidupan Seorang Nenek" karya NH. Dini. Tokoh Aku yang berbudaya Jawa berusaha beradaptasi dan melebur dengan budaya Bali suaminya. Ketika muncul konflik, tokoh Suami berusaha menghargai keinginan istrinya untuk tidak dibebani dengan tanggung jawab mengurusi semua ritual budaya Bali yang menyita waktu. Sikap saling menghargai itulah yang membuat hubungan rumah tangga mereka tetap baik-baik saja meskipun didera konflik.

Sikap saling berbagi tergambar dalam cerpen "Sang Primadona" karya A. Mustofa Bisri. Tokoh Aku dan suaminya terlihat saling berbagi peran dan berbagi dukungan dalam menjalani hubungan rumah tangga mereka. Sikap tersebut yang membuat mereka mampu melewati masalah ekonomi di rumah tangga mereka.

Ketiga sikap tersebut merupakan wujud sinergitas yang terjadi dalam hubungan bermasyarakat. Ketiga sikap dan perilaku tersebut adalah kata kunci kesetaraan gender. Setara berarti bersinergi dalam berbagai bidang kehidupan (McRobbie, 2004: 260).

Berdasarkan analisis hasil penelitian diketahui bahwa cerpen-cerpen tersebut mengandung nilai-nilai kesetaraan gender. Cerpen-cerpen yang mengandung nilainilai kesetaraan gender dapat digunakan untuk memberikan contoh kepada siswa tentang hidup bersinergi antara laki-laki dan perempuan. Hal itu sejalan dengan UU Sisdiknas tahun 2003 yang menyebutkan bahwa mencontohkan merupakan salah satu cara untuk menanamkan karakter sejak dini kepada siswa.

\section{SIMPULAN}

Berdasarkan temuan penelitian dan pembahasan penelitian diperoleh simpulan bahwa tokoh laki-laki dalam cerpen pada umumnya memandang perempuan sebagai seseorang yang berhak mendapatkan kesempatan berkarier di luar rumah, teman dalam rumah tangga, teman berdiskusi, dan penentu keputusan. Citra setiap tokoh dalam cerpen-cerpen yang dianalisis ini tergambar sangat jelas. Perempuan pada umumnya dicitrakan sebagai perempuan yang mengurusi urusan domestik rumah tangga. Meskipun ada yang dicitrakan sebagai perempuan yang bekerja di wilayah publik, ia tetap tidak melepaskan peran pentingnya dalam wilayah domestik rumah tangga. Hal tersebut menunjukkan bahwa perempuan memiliki kemampuan mengembangkan kariernya di ruang publik, tetapi tetap mampu melaksanakan tugasnya dengan baik dalam ruang domestik rumah tangganya.

Berdasarkan analisis peran, peran perempuan yang paling menonjol adalah peran domestik. Sebagai pribadi, perempuan mempunyai keinginan mengaktualisasikan dirinya untuk mengembangkan potensi dirinya. Dalam mengaktualisasikan diri inilah mereka mendapatkan kepuasan batin karena mereka dapat mewujudkan aspirasinya, mampu menemukan jati dirinya, dan dapat memperoleh kelebihan finansial. Salah satu bentuk mengaktualisasikan diri inilah dengan bekerja di ruang publik. Pemikiran itu lahir dari pemahaman tentang perbedaan laki-laki dan perempuan, yang memang nyatanya berbeda. Kenyataan atas perbedaan tersebut membuat kesetaraan mutlak yang selama ini menjadi tuntutan kaum feminis menjadi hal yang tidak mungkin dicapai. Jadi, bagi kaum posfeminis, daripada be- 
debat tentang kesetaraan yang memang tidak mungkin dicapai karena sejatinya lakilaki dan perempuan itu berbeda, lebih baik mendorong kaum perempuan untuk memaksimalkan potensi-potensi yang terdapat dalam dirinya sebagai perempuan dan menjadi pribadi unggul atas potensi feminin yang dimilikinya itu.

Secara garis besar, aspek kesetaraan gender yang terdapat dalam cerpen-cerpen yang dianalisis terlihat dari sikap dan perilaku yang dikelompokkan menjadi tiga, yaitu saling memahami, saling menghargai, dan saling berbagi. Ketiganya merupakan wujud sinergitas yang terjadi dalam hubungan bermasyarakat. Ketiga sikap dan perilaku tersebut adalah kata kunci kesetaraan gender. Nilai-nilai kesetaraan gender tersebut diperoleh dari hasil analisis citra, peran, dan pandangan tokoh lakilaki dan perempuan dalam setiap cerpen. Setara berarti bersinergi dalam berbagai bidang kehidupan.

\section{UCAPAN TERIMA KASIH}

Artikel ini diangkat dari penelitian disertasi di Program Doktoral Pascasarjana Universitas Negeri Jakarta (UNJ). Ucapan terima kasih disampaikan kepada Prof. Dr. Emzir, M.Pd. dan Prof. Dr. Sabarti Akhadiah selaku Promotor, Dr. John Pahamzah, M.Hum. sebagai penelaah, dan semua pihak yang telah membantu menyelesaikan penelitian ini dan menerbitkan artikel ini dalam bentuk jurnal.

\section{DAFTAR PUSTAKA}

Arvanitaki, E. 2017. "Postmillennial Femininities in the Popular Romance Novel", Journal of Gender Studies, hlm. $1-11$.

Djoharwinarlien, Sri. 2012. Dilema Kese- taraan Gender (Refleksi dan Respons Praksisi). Yogyakarta: PolGov Fisipol UGM. Fraenkel, Jack R dan Norman E. Wallen. 2007. How to Design and Evaluate Research in Education. New York: Mc Graw.

Haryanti, A. \& Suwana, F. 2014. "The Construction of Feminism in Indonesia", Procedia, Social and Behavioral Sciences, Volume 155, hlm. 236-241. http: / / ec.europa.eu / dgs / education_culture/repository/ education/policy/school/doc/ teachercomp_en.pdf.

Mazaya, V. 2014. "Kesetraaan Jender dalam Perspektif Sejarah Islam", Jurnal, SAWWA, Volume 9, Nomor 2, hlm. 323-343.

McRobbie, A. 2004. "Postfeminism and Popular Cultures", Feminist Media Studies, Volume 3, hlm. 255-264.

Mukhopadhyay, M. 2005. A Guide to GenderAnalysis Frameworks. UK, An Oxfam Publication https://ndi.org/default/ files/Guide $\% 20$ to $\% 20$ Gender $\% 20$ Analysis\%20Framework.pdf. (Diunduh Tanggal 1 Maret 2018).

Murata, Sachiko. 1997. The Tao of Islam (Kitab Rujukan tentang Relasi Gender dalam Kosmologi dan Teologi Islam). Bandung: Penerbit Mizan.

Purwati, Budi Dewi. 2011. "Nilai-nilai Akhlakul Karimah dalam Novel Anak di Indonesia tahun 1921-2010", Litera, Jurnal Penelitian Bahasa, Sastra, dan Pengajarannya. Volume 10, Nomor 1,hlm. 23-34.

Rahmawati, Aulia. 2018. "Romansa dan Femininitas dalam Film Remaja Indonesia: Sebuah Tinjauan Postfeminisme Transnasional", Jurnal Perempuan: untuk pencerahan dan kesetaraan, Volume 23, Nomor 1, hlm. 43-62. 
Sooraj. 2013. Education System: A Narration on Education; The Role of Textbooks in Education (Texts and Books). Jakarta; Adm. Publish https:// educational-system.blogspot.com/ co.id. (Diunduh Tanggal 1 Maret 2018).

Sugihastuti dan Saptiawan, Itsna Hadi. 2010. Gender dan Inferioritas Perempuan. Yogyakarta: Pustaka Pelajar.

Suyadi. 2013. Strategi Pembelajaran Pendi- dikan Karakter. Bandung: Remaja Rosdakarya.

Undang-Undang Sisdiknas. 2003. UndangUndang Sistem Pendidikan Nasional, Nomor 20 Pasal 3: Pendidikan Karakter. Jakarta: Depdiknas.

USAID PRIORITAS. 2013. Modul Paket Pelatihan Pembelajaran yang Efektif tingkat SD/MI dan SMP/MTs: Modul I. Jakarta: USAID PRIORITAS. http:// prioritaspendidikan.org/id. 